\section{Sports Marketing and Perceived Value: an application of the conjoint analysis in the Fan Membership Programs of Football}

\author{
Pâmela de Souza Dias ${ }^{1}$ \\ pandjoca@yahoo.com.br| (1D0000-0002-5849-3886 \\ Plínio Rafael Reis Monteiro ${ }^{2}$ \\ preisufmg@gmail.com | (D) 0000-0002-5626-2945
}

\begin{abstract}
Football is ever present in Brazilians' lives, and, more than a game, it also involves social and economic relations. Fan Membership Programs (FMPs), based on relationship marketing strategies, are ways to bring the clubs closer to their fans. This paper aims to analyze the perceived value structure of FMPs, based on sociodemographic profiles, starting with FMP attributes of the 2016 Brazilian Football Championship series A classified clubs. The data was collected online, and the population consisted of fans of the selected teams. The data was analyzed using the multivariate technique of Conjoint Analysis. It was verified that the general sample for different sociodemographic profiles, the ticket discounts, and prices of the FMP are the most valued attributes. This paper contributes to academy and practice by presenting a capable instrument to describe FMPs' value perception. In academic terms, it contributes as a sports marketing management study. In addition, the paper could also apply as a tool for the Football clubs' managers.
\end{abstract}

\section{KEYWORDS}

Fan Membership Programs, perceived value, conjoint analysis, sports marketing.
${ }^{1}$ Faculdade de Economia e Administração, Universidade de São Paulo, Ribeirão Preto, SP, Brasil

${ }^{2}$ Faculdade de Ciências Econômicas, Unversidade Federal de Minas Gerais, Belo Horizonte, MG, Brasil

Received: 02/14/2019.

Revised: 07/01/2019.

Accepted: 08/06/2019.

Published Online: 03/09/2020.

DOI: http://dx.doi.org/10.15728/bbr.2020.17.3.1 


\section{INTRODUCTION}

Football is a sport with great popular participation and an activity in which the audience demonstrates significant attachment for its teams (Scharf et al., 2016). Since beginning with, "the first match organized by Charles Muller in our territory, still in the nineteenth century, through the transformation from an elite sport to a popular phenomenon" (Martins, 2016, p. 8 independent translation), football in Brazil acquired several peculiarities. As suggested by Martins (2016), there is a growing appreciation of the presence of fans in the stadium, as this experience tends to be more satisfactory when compared to television and other mass media.

Football is an everyday form of Brazilian cultural expression, holding significant social and economic impact (Martins, 2016). Considering the influences mentioned above, one can state that football is a market with varied offers, such as athletes, teams and events. In addition, when it comes to attracting fans, athletes and teams, their importance stands out. However, in the case of collective modalities, there is a difference, "because while an idol has a shorter life cycle, teams tend to remain." (Martins, 2016, p. 22 independent translation).

All of this popularity has resulted in millions of players and attracted billions of fans. Thus, it has become a business, which generates enormous revenues (Müller, Simons, \& Weinmann, 2017). One factor that justifies the quest for better balance in revenues and expenditures, is the recurring news of Brazilian clubs experiencing administrative problems. Difficulties range from excessive indebtedness to involvement in ethical and legally questionable issues (Marques \& Costa, 2016).

The adoption of good management practices, through administrative professionalization initiatives, and the alignment of different stakeholders with the goal of achieving long-term sustainability, is a way to soften this scenario. In addition, the "adoption of this type of practice can even be a differential in the search for capital and other resources, by stimulating a better administrative structure of clubs." (Marques \& Costa, 2016, p. 401 independent translation).

Fans' engagement with their clubs is a differential for marketing actions. It is more effective when compared with conventional segmentation approaches that rely on demographic variables to reach their target audience, such as, income, region, gender and age (Fleury et al., 2016). Thus, opportunities to create marketing actions to improve return on investment are substantial.

The Fan Membership Programs (FMPs), which is a proposal inspired by the European clubs, stands out in this direction, being a viable alternative to increase revenue and make the modernization projects of Brazilian clubs' feasible. In addition, FMPs act as mechanisms to improve the relationship between clubs and supporters, broadening the knowledge of public loyalty (Martins, 2016). As stadiums are places of interactions between multiple stakeholders (sponsors, investors, governments, and telecommunications), it may be suggested that while sports can be considered as a spectacle and a popular form of entertainment, FMPs are a practice that allow the club to strengthen its relationship with its fans. (Martins, 2016).

With practices such as Football FMPs, this relationship marketing adoption has achieved widespread success in Europe, where European clubs pioneered the club-related products and services offering (Martins, 2016). Sport Club International was the first Brazilian club to conceive and carry out philosophies that put fans as the focus of their business, making them the pioneer of Brazil's FMP creation in 2002 (Avancini et al., 2010). 
Brazilian football clubs sought to adopt their Fan Membership Programs in order to increase their revenues with the public in the stadiums, (Martins, 2016), as fans who are also members, buy tickets with advantages, besides having access to other benefits (Itaú BBA, 2016). In Brazil, one of the main supporters of FMPs is the "Movement for Better Football", which aims to foster partnerships between large companies and the teams. Such movements aim to "leverage fan club programs in Brazil by offering many brands, products and service discounts to participants" (Martins, 2016, p. 11 independent translation).

Marketing employs the concept of perceived value as a starting point for the construction of new offers. Considering that football has a significant public variety, such a concept includes the need to map the different decisions of these sport fans. The perceived value is composed of qualitative, quantitative, objective, and subjective factors, which form the users' experience. The proportion of costs, in relation to the perceived benefits, implies the perceived value. Therefore, it is "the consumer's overall assessment of the utility of a product based on the perception of what is received and what is given" (Yang et al., 2016, p. 257).

Hence, understanding and quantifying the consumer's perceived value is a required step to delivering a valuable offer. In this way, the value analysis is a step that must precede an FMP strategy. To accomplish this analysis, researchers who are investigating the consumer decision process usually rely on the use of Conjoint Analysis (Nuraeni, Novani, \& Arru, 2015).

The purpose of this paper is identifying the perceived value structure by means of sociodemographic segments, in a set of attributes as offered by Fan Membership Programs of the 2016 Football Brazilian Championship series A clubs.

This article is organized as follows: the next section presents the theoretical foundation; the third section describes the methodological procedures; the fourth section presents the results analysis; and the last section reports the conclusions of this study, as well as the limitations and suggestions for future research.

\section{BACKGROUND}

\subsection{Sports Marketing}

The term sports marketing relates to brand marketing through sports. It is a part of an organization's activities that utilizes sports to identify, propose and communicate value proposals that satisfy the diverse stakeholders of the sports environment, such as supporters, sponsors and team managers (Pozzi, 1998).

Pitts and Stotlar (2002, p. 90 independent translate) define sports marketing as the "process of designing and implementing production, pricing, promotion and distribution of a sports product" in a way that satisfies consumers and, consequently, the organizations involved.

Sports marketing's origins date back to 1880 and 1920, when elements still associated with the concept emerged, such as product planning, development, administration, distribution, pricing, and promotion. Before that, little was considered about consumer demand and other marketing elements. Nevertheless, from 1820 to 1880 there were already strategies implemented to attract the public to sports events, through the most popular athletes' advertisements and championships. In addition, ticket payments were already taking place. Finally, between 1920 and 1990, with an increase in popularity and more diversification of sports, there was significant market growth. Technological changes transformed manufacturing processes, influencing the 
BBR

17

256

quality and performance of products; and consequently, athletes' performance and sports industry information access (Pitts \& Stotlar, 2002).

Historically, relationship marketing with football began after the Second World War, when researchers developed interest in this attraction, glimpsing the sport's ability to expose brands and offers associated with football teams (Myskiw, 2006). Fans have become the main players (This is another form of saying, "Actors." I thought it would be a nice play on words. However, the choice is yours if you'd like to use it or not) of the football market. This reinforces the importance of studying their differences, as well as the need for clubs to establish reciprocal relationships with fans in order to increase their brand levels (club) internalization and contribute to increasing positive behavioral intentions. For example, displaying photos of fans on the club's website, or offering free tickets for bringing friends to games are strategies that can create a higher level of value between the supporter and the team (Biscaia et al., 2016).

Many sports organizations, especially small ones, designate sports marketing responsibility to an employee who has no experience. However, such an attitude can be detrimental to team goals, mainly in sports marketing plan development and implementation, which can be complicated (Dickler, 2015).

Sports sponsorship is the sports marketing strategy that had attracted increased attention in the last few years, and consequently, it is often jumbled with sports marketing by the amount of investments. Due to the new consumer's demands, as well as the search for a communication differentiation by the most varied organizations, this strategy has already become popular for its visibility, traditional advertising, and sales promotions (Lois, 2013).

Brazil has increased its importance in the sports industry, mainly for recently hosting two of the world's major sports events, the Football World Cup (2014) and the Olympic Games (2016). This could be a significant factor for increasing sports marketing publications in the last few years. Moraes (2017) points out that academic production in the area underwent a gradual growth starting in 2005, with emphasis from 2013 to 2017. However, the studies are still considered recent and small in quantity, focusing on fans and sponsorships, with little work done on clubs' marketing management.

Despite the increasingly professional administration within sports organizations, there are still some questions about the extent to which the sector requires managerial specific treatment at the academic or practitioner level. For example, looking at the marketing generalizations applied to sports, one noted that, unlike the common market, fans are not likely to switch between "competing brands" (teams) because they are loyal to their teams. Figure 1 shows the main moments experienced by Sports Marketing. Thus, the presence of patterns in sports consumer

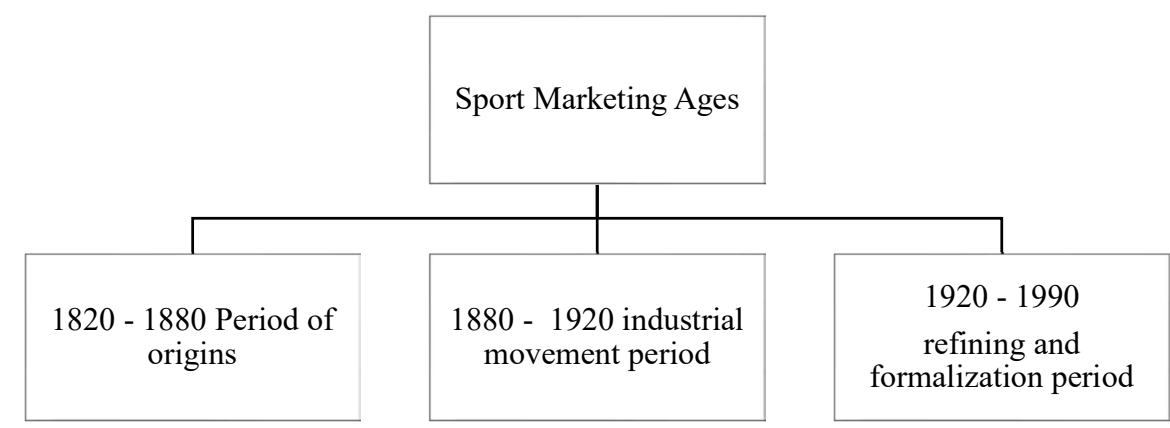

Figure 1. Sports Marketing Ages

Source: Adapted from Pitts and Stotlar, 2002, p. 54 
behavior suggests that the adaptations need to achieve the best practices (Baker, McDonald, \& Funk, 2016).

Therefore, it is not recommended to adopt strategies focused exclusively on a small number of fanatical fans, those who have a high involvement in and a high consumption of sports related products and services, but to invest in a broader fan base. In this case, the challenge is to determine effective ways to build a psychological bond and expand the availability of offers, especially tangible ones, to fans (Baker, McDonald, \& Funk, 2016).

Whether in the role of supporter, sympathizer, or as a modality practitioner, the supporter is a member of the public who is remarkably true to his favorite sport. This is an advantage with possibilities to explore in sports marketing. The fan's involvement provides a relationship marketing development with the possibility for a lasting relationship (Lois, 2013).

\subsection{Relationship Marketing}

Literature points out that relationship marketing can be defined, as suggested by Berry (1983), as "the set of practices, philosophies and mechanisms to attract and retain customers. It essentially has the ability to satisfy them in order to maintain a lasting relationship" (Berry, 1983; Caliskan \& Esmer, 2019; Hennig-Thurau, Gwinner, \& Gremler, 2002; Sheth \& Parvatiyar, 1995).

Authors such as Morgan and Hunt (1994) extend this view by suggesting, "Relationship marketing refers to all marketing activities aimed at establishing, developing, and maintaining successful relational exchanges" (p.34 independent translation). Such exchanges involve suppliers, partner organizations, consumers, employees and business units. As such, this concept is not restricted to customer-business relationships. Commitment and trust built on "providing resources, opportunities, and benefits that are superior to alternative partner offerings" (p.22, independent translation) maintain high corporate values standards, align with production chain links and have synergy in their value system. Communication emerges as a central element of this process, as it is necessary to manage the market-supplier information flow through marketing channels, generating information flows that support strategic marketing decisions.

Finally, Grönroos' (1994) definition, supported by his previous articles published in 1989 and 1990 , states that relationship marketing is a process that includes various partners or actors, like consumers, whose goals must be fulfilled. This is done by mutual exchange and fulfillment of promises, which makes trust a central aspect of relationship marketing.

All relationship marketing actions are focused in achieving current or long-term profitability. However, there are numerous variables that influence an organization's profitability, which are not necessarily related to specific loyalty actions. For example, it is important to improve consumer confidence, since this construct is the basis for solidifying relationships and, consequently, for improving business performances (Lo \& Campos, 2018).

Relationship marketing is a way to help managers conquer new users and, especially, maintain the existing ones. Brazilian Football teams already adopted this practice when they realized that their supporters increased engagement, and that this could improve revenues. This stimulated the investment in tools aimed to provide a closer relationship with their fans (Chaves, Gosling, \& Medeiros, 2014).

It is necessary to highlight the importance of keeping up with technological trends in combination with relationship marketing strategies. Such actions help organizations stay competitive and profitable, especially when given the growing online shopping popularity that has resulted in significant expansion of investments in digital channels. Therefore, the time has come to explore 
BBR

17

258

different ways of communicating with consumers, bringing a much broader and independent method of managing customers touchpoints or customer's life cycle stage (Lo \& Campos, 2018).

In relationship marketing literature, there are commonly found associations with loyalty and satisfaction variables (Demo et al., 2015). Satisfaction refers to the difference between the customers' perceived ideas and expectations. Satisfaction has a significant effect on loyalty, which is related to the organization's performance (Kasiri et al., 2017).

Multiple combinations determine consumer satisfaction. The organization's ethical standards and the congruence between consumer values and brand goals lead users to conclude that the company is committed. Such a commitment generates greater satisfaction and trust with the service. When this belief is established, consumers are more satisfied and feel more confident, remaining loyal with a continuous and affective organization commitment (Park, Kim, \& Kwon, 2017).

Regarding loyalty, Oliver (1997) states that maintaining a deep commitment prolongs customer's association with the company. Such a thing is continuous and resists situational influences and external marketing efforts. A loyal consumer does not change his posture easily through competition efforts nor, in the case of sports, whether other teams perform well.

The satisfaction can be specific or cumulative. The specific, also called "performance satisfaction", refers to short-term encounters or a specific transaction. On the other hand, the accumulated, or relationship satisfaction, occurs in long-term transactions (Rossi \& Slongo, 1998). In the context of sports, one can relate to watching a game in the stadium as a specific satisfaction, while following an entire annual championship as an accumulated satisfaction.

As previously mentioned, besides strengthening loyalty, satisfaction is important to build an organization's positive communication. An unsatisfied consumer will probably communicate his negative experience to others. The brand's previous performance cumulative evaluation and future dissatisfaction likelihood increase the willingness to alert people not to be involved with the organization (Weitzl, Hutzinger, \& Einwiller, 2018).

Claro and Bortoluzzo (2015) defined that "rumor agents" are influential groups in the market. For instance, a fan can influence other people to acquire clubs' offers. Maintaining a close and lasting relationship with consumers, supported by the satisfaction pursuit to consolidate trust, favors organizations to show competitors superior value. In addition, long-term relationships may mean getting data that is more relevant. Thus, consumers tend to be more willing to give companies direct feedback, providing high quality information to improve business strategies (Lo \& Campos, 2018).

Despite the numerous advantages mentioned, one must also consider the possible disadvantages of long-term consumer relationships. For example, it is bad for both the user and the organization to make efforts to maintain a relationship that has not met the consumer's needs, such as offering a full-time class to a student with a job. In addition, some users are not profitable, even when they have their needs fulfilled. There is also the case of new ventures where revenues are not high enough to cover the costs of a relationship program. Besides, there are consumers with a history of insolvency, representing a risk to the organization (Zeithaml, Bitner, \& Gremler, 2014). 


\subsection{Customer value}

Perceived value is a general evaluation of what is received (benefits) in relation to what is given (sacrifice) by the customer. Such a definition considers product quality, service, price affordability, and the shopping experience. Perceiving value in an exchange is a requisite step to fulfilling customers' needs and achieving satisfaction. The consumer's behavior decision process depends on the assessment of the value in an offer, being a central tenet of the customer's decision. In this way, understanding the underlying factors of value structure is important to allow managers to deliver desired value proposition to consumers (Chang \& Dibb, 2012).

Offering high-quality products/services is mentioned as an antecedent of the perception of superior value, especially as consumers have become more selective by looking at the total cost, not just the monetary. Thus, other types of costs are becoming more prominent, such as time, knowledge, and maintenance (Berry, Zeithaml, \& Parasuraman, 1985).

However, it is possible to interpret what motivates users' specific choices based on value perspectives. When it comes to functional value, the consumer evaluates the utility, or physical capacity, in the offer acquired. Social value is associated with one or more social groups' aspects in this consumer context, whether they may be positive or negative. Similar to this, emotional value refers to an offer capable of arousing feelings or affective states in the user. Epistemic value, usually, involves a curiosity or novelty. Lastly, the conditional value results from a specific situation or set of circumstances that motivate a choice. Consumer behavior can be influenced by any of the five values, by a combination of them, or by the five together (Sheth, Newman, \& Gross, 1991).

Regarding social value, Hills, Walker and Barry (2019) add that the most demanding consumers seek commercial and social value synergistically, as do sports organizations. Therefore, the adoption of shared-value practices, meaning the economic value non-prioritization over social value, is welcome. In this case, value is a multidimensional construct, considered as one of the most significant concepts to understanding consumer satisfaction, including hedonic and utilitarian values as essential to understanding the consumer's buying decision. Hedonic values refer to a general benefits and sacrifices assessment, such as a leaning toward pleasure and fun, while utilitarian values consider functional benefits and sacrifices, such as economic value and time. Both exert different influences on behavioral intention (Shin, Kim, \& Severt, 2019).

In the context of Football, when considering clubs as products, one can notice a variety of target markets. Thus, the fans can consider the perceived value intangible and the partners, from different segments, can consider different values. These characteristics allow club managers to develop value propositions and capitalize upon offers on comprehensive attributes, individually and collectively, positioning their value according to the images and associations they desire. Therefore, related to Football, the value definition must go beyond the conceptual, encompassing identification with target markets and supporters (Vrontis, et al., 2014).

So, clubs should highlight aspects of success on the pitch, their management commitment and competence, their long-standing club traditions, and their home stadium characteristics to properly manage the team's brand, in order to attract supporters and stakeholders (Biscaia et al., 2016). 
BBR

17

260

Therefore, managers and marketers must have a deep understanding of the concept of perceived value in order to satisfy them. A value proposition acts as a differential for organizations to achieve satisfactory performance. In this context, market segmentation also becomes important as it directs the company to its target audience. In addition, it is advantageous to choose and maintain the right partnerships, thus devising, a unique value proposition that is hard to copy (Souza \& Batista, 2017).

\subsection{Fan Membership Programs and loyalty Programs}

Loyalty programs emerged in the airlines industry. American Airlines pioneered the start of such a program in May 1981. Due to its success, issues related to manageability and maintaining member satisfaction were raised. Therefore, in recent years, programs have evolved from their initial static designs to more sustainable and profitable structures, developing program mechanics and management structures (de Boer \& Gudmundsson, 2012).

Loyalty programs provide rewards to members. Organizations evaluate the offered benefits effect in order to identify effective ones and to eliminate those that have unsatisfactory results. Effects that are potentially negative, represent a major impediment to the advancement of relationship marketing. Thus, the analysis of the program helps managers to better identify weaknesses that can undermine performance (Steinhoff \& Palmatier, 2016).

A variety of formats is found in such programs, but the points-to-reward system and consumerrating levels are the most common. In the first instance, relationship points are calculated, which may be converted to prizes. In the second model, when repurchases become more frequent or if customer revenues increase, the consumer is classified as special (eg, VIP customer), receiving benefits for this condition (Septianto, An, Chiew, Paramita, \& Tanudharma, 2019).

Marketers must identify the most efficient strategy for each model. Septianto, An, Chiew, Paramita and Tanudharma (2019) found that emotions, such as happiness and pride, influence the performance of the loyalty program. While such emotions have an effect in both programs: (accumulation of points and consumer level), pride has the greatest impact on consumer-level models, as it provides the opportunity to signal status, which is consistent with the pride function. Overall, increasing an emotion's pleasure leads to greater repurchase intentions. Such emotional appeals can be used together by different media or campaigns and not just with the loyalty programs (Septianto, An, Chiew, Paramita, \& Tanudharma, 2019).

This perception is also recognized among Brazilian football teams, as they realized that greater audience engagement can increase revenues (Chaves, Gosling, \& Medeiros, 2014), especially with the Fan Membership Programs. Such programs are innovative loyalty models that have been successful in the main European clubs, which has encouraged Brazilian clubs to implement it. National clubs explore the program's greater potential, enabling clubs' revenues to be "less dependent on-field results, with fluctuations much lower than those found in box office revenues" (Cardoso \& Silveira, 2014, p. 21 independent translation).

By joining an FMP, the supporter pledges to pay a monthly fee in exchange for benefits, such as buying tickets in advance and, depending on the plan, having a discount related to the box office anticipation revenue. In games with a small turn out of fans, part of the tickets' revenue will already be guaranteed with the members' monthly payment of fees. Therefore, it is characterized 
as a relevant investment for the clubs, narrowing, in this way, the relationship with the potential supporter who contributes spontaneously and also invests effectively in the team (Itaú BBA, 2016).

FMP is an available alternative to decrease teams' dependences on revenues from the box office and sales of players' passes. Gaspar et al. (2014) analyzed five national clubs with Fan Membership Programs, and although each team had its own models, similar benefits were found among the packages offered, such as discounts, the possibility of acquiring tickets in advance, the accumulation of points for discounts at stores, and for purchasing tickets through the internet. During this period, the master sponsor and the Fan Membership Programs were significant in the teams' annual revenues.

It is still worth highlighting that box office revenues are inconsistent, because teams' performance in the championships influences fans' presence in the stadiums. In addition, the most involved fans, or the loyal fans, are the ones who frequent the stadiums more, but this group is only a portion of the total. Therefore, if clubs work more effectively in the Fan Membership Programs, they can achieve a significant increase in revenues and reduce the variability in their cash flows (Cardoso \& Silveira, 2014).

Football is Brazil's most popular sport and has a significant economic movement generated by clubs, athletes, regulatory authorities, and fans throughout the country. Clubs bring in funds in a variety of ways - through the sales of shirts and other products, through ticket sales of the games, as well as a greater number of subscriptions in Fan Membership Programs, with sponsors, besides the revenues achieved with matches broadcast through television networks (Figueiredo, Santos, \& Cunha, 2016).

Due to football's significant popularity, it has become necessary to encourage greater responsibility in the clubs' management, especially regarding their financial aspects. International Football Federation (FIFA) has determined that the South American Confederation of Football (CONMEBOL) should issue a regulation license to be the basis of the affiliated federations, among them the Brazilian Federation (CBF). As stated by Marques \& Costa (2016, p. 386 independent translation) such regulations "are those related to compliance with national law, compliance with FIFA standards, and conditions for the provision of license to participate in competitions".

In marketing terms, club managers seeking better competitive outcomes should reevaluate factors such as brand, communication and competitors, which are relevant in the football industry. Concerning competitors, it is about hiring future athletes, fundraising with good sponsorships and even finding ways to beat competing teams in championships. Good communication strategies make the team well accepted and recognized in the football environment. Television is a great ally in this process because it has global game broadcasting capabilities and it is an important time for the club to convey its message to the public (Costa et al., 2018).

However, it is necessary to assess the situation holistically and consider issues such as the behavior of fans in stadiums and their influence on box office results. For example, sports organizations can influence fans by striving to increase environmental sustainability initiatives, by raising fan awareness and participation in those efforts, thus contributing to more enjoyable stadium experiences and expanding potential sponsorship possibilities (Casper, McCullough, \& Pfahl, 2019). 
BBR

17

262

\subsection{APPLICATION OF THE CONJOINT ANALYSIS}

Conjoint analysis (CA) is a widely used technique to measure consumer preferences for products. It relies on an experimental approach that involves a combination of attributes and levels, resulting in offer options represented by an array. The experimental model generates reliable statistical estimates of the value attached to product attributes (Huertas-García, NuñezCarballosa, \& Miravitlles, 2016).

Conjoint analysis (CA) is a popular technique used by researchers to investigate purchase decisions related to product or service characteristics. The technique promises to help understand consumer choices, and in doing so, indicate which attributes are considered the most important and which combination (between attributes and levels) is the most preferable (Nuraeni, Novani, $\&$ Arru, 2015). Therefore, organizations can make offers that are more appropriate to their target audience.

$\mathrm{CA}$ is a technique that seeks to identify the structure of preferences behind the attribute levels of a product or service, studying their joint effect on consumer value. It is an effective alternative for marketers who need to identify the processes with which consumers compare and evaluate products based on their characteristics or resources (Anand, Bansal, \& Aggrawal, 2018).

Besides the research results interpretation, $\mathrm{CA}$ is also used in the fractional factorial design conception (Hair, et. al 2005). To implement CA, an important step is to build one experimental design with a combination of attribute levels to represent a choice set to be presented to the respondent. Experimental design is a numerical arrangement that combines attributes and levels to form stimuli (product or service concepts) that will later be evaluated by potential consumers. There are several ways to organize the stimuli, but full factorial design is the easiest, as all possible attributes and levels combinations are simply presented (Huertas-García, Nuñez-Carballosa, \& Miravitlles, 2016). However, in practical applications, full factorial design results in many options, making it not feasible to present all options to the consumers' assessment.

For these designs to achieve maximum statistical efficiency, they need to be orthogonal and balanced, which is only possible with designs that require few variables and few levels. Thus, most experimental designs are almost orthogonal (Huertas-García, Nuñez-Carballosa, \& Miravitlles, 2016). A common assumption is that CA parameters are independent of the particular set of alternatives under study. However, it is known that changes in the alternative numbers and their attributes can affect how choices are made when a compensatory model erroneously represents a "true" and non-compensatory choice process (Johnson \& Meyer, 1984).

When deciding to use the CA for the instrument development, the researcher needs to define whether it is feasible to opt for the full profile approach or for a fractional factorial delimitation for the stimulus combinations. For instance, consider the desire to evaluate a soap product with two attributes and two levelsls each. The full profile approach would result in four (4) stimuli combinations for respondents to assess their preference, as shown in Chart 1. 
Chart 1

Example of elaboration of an instrument using the conjoint analysis

\begin{tabular}{llll}
\hline & Attribute: shape & Attribute: aroma & Resultant combination \\
\hline Level & Powder & Neutral & Soap in powder and neutral \\
Level & Powder & Fragrant & Soap in powder and fragrant \\
Level & Liquid & Neutral & Soap liquid and neutral \\
Level & Liquid & Fragrant & Soap liquid e fragrant \\
\hline
\end{tabular}

Source: Prepared by the authors

Traditionally, conjoint analysis bases on consumer choices and the assumption that respondents made rational decisions using all available information. However, several studies suggest that people ignore some information when making their choices. Respondents may use simple strategies or a common heuristic, known as attribute non-attendance (ANA), displaying that they ignored one or more attributes when making their choices (Yegoryan, Guhl, \& Klapper, 2019).

Literature points out that visual attention and ease of information processing may depend on its visual characteristics, such as the size or color employed in the study. Therefore, when organizations need to differentiate their products into such attributes, it is essential to focus on the appropriate segment, consumers familiar with the attribute rather than the entire population (Yegoryan, Guhl, \& Klapper, 2019).

\section{METHOD}

This study utilizes both descriptive and quantitative research. The data was collected by a virtual self-completion survey elaborated in two stages. Firstly, the respondent was evaluated using the real plans of his favorite team's FMP and what he would be more likely to acquire. Then, he was evaluated in the same way using a Likert scale of 10 points 16 fictitious plans.

The fictitious plans were elaborated for Conjoint Analysis estimates. Such plans were derived from the benefits identified in FMPs of 20 teams from the 2016 Brazilian Football Championship series $\mathrm{A}$, which was summarized in six main attributes, a mix of nominal and scale attributes. Typical values found in real FMPs in the market were the source for determining the values, range, and level for each attribute.

The option was to use a fractional factorial design for stimuli combinations. The design is comprised of six attributes, three attributes with three levels and three attributes with two levels. It would be impracticable to opt for the full profile approach because the instrument would have 72 stimuli $\left(3^{3} \times 3^{2}\right)$ which would require more time and effort from the respondent, rampaging the responses rate and quality.

Figure 2 demonstrates the six chosen constructs. In the price, the levels 20, 40, 100 and 140 Brazilian reais were presented to the respondents. The discount on tickets had the options of $30 \%, 60 \%$, and $90 \%$. The benefits attribute was related to partnerships, with the options, "movement for better soccer", "discount in the partners' network" and "official stores' discount". For the anticipated purchase and privileged area, the respondent only opined in a binary form (yes or no). Finally, the number of invited and family (dependents) had the levels one, two or three guests. 
BBR

17

\section{4}

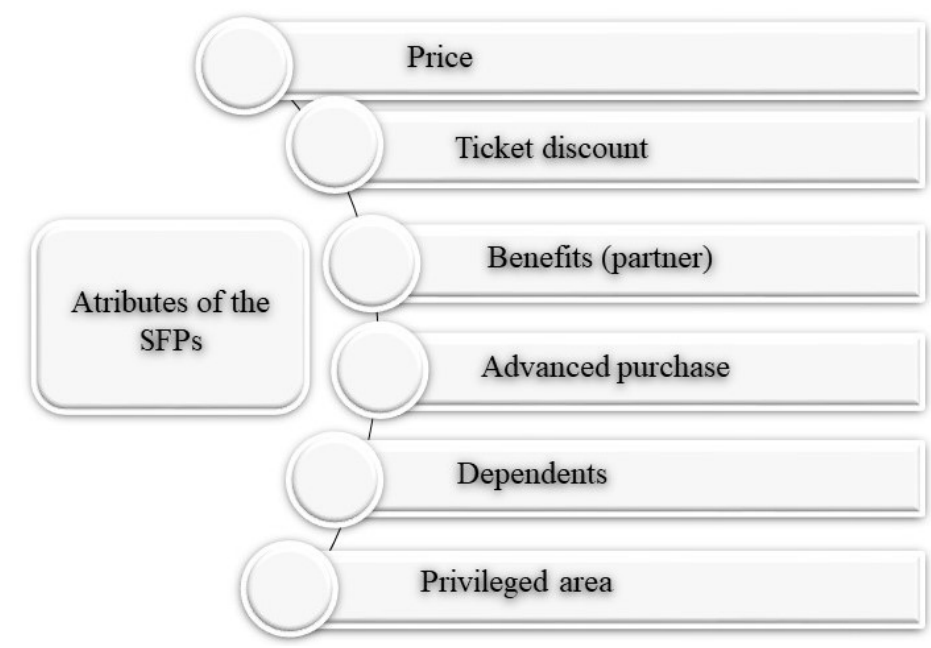

Figure 2. Constructs used in the instrument

Source: Prepared by the authors

A convenience sampling was adopted, while the target population was derived from estimates on the number of fans between 2015 and 2016 (survey). It is worth mentioning that even with a large and unknown population size, we used the standard $5 \%$ margin of error and $95 \%$ confidence level, the minimum sample size goal was 386 , and the research gathered information from 436 valid observations.

A pre-test was performed and applied to respondents with the same profile of the target population, to verify issues that could hinder the questionnaire interpretation. The dubious points were modified, and the pre-test reapplied. Next, it was verified if the CA design was coherent before deriving to the ultimate survey. The questionnaire was applied through SurveyMonkey ${ }^{\circ}$ sending the links to emails, social networks, and WhatsApp groups related to the selected Football clubs.

The questionnaire used a forced response approach, so all responses were mandatory. In this way, there was no missing data. Of the 584 partial respondents, 87 interrupted the questionnaire, corresponding to $14.9 \%$ of the entire database. In addition, 43 respondents evaluated the 16 fictitious plans with the same note, making the estimation by CA impossible (since the dependent variable $\mathrm{Y}$ become constant). These cases were also removed from the sample, corresponding to $7.3 \%$ of the results. In total, the data loss corresponded to $22 \%$ of the potential database.

Univariate outliers were analyzed using $\mathrm{Z}$ scores and the Mahalanobis distance was used to classify multivariate outliers. Using these approaches, six atypical observations were found, which were all positive outliers ( $\mathrm{Z}$ greater than 2,58), none of the multivariate form. Such responses were excluded from analyses.

To check the CA reliability, the Kendall correlation measure was employed, which indicates if there is a consensus between the original responses and those estimated by the model. A significance level of $5 \%(\mathrm{p}<0.05)$ was applied and used for this finality (Benitez \& Golinski, 2007). Traditionally, the cut-off point of the p-value to reject the null hypothesis is 0.05 (Ferreira $\&$ Patino, 2015). Twelve non-significant individual results were found, which were excluded. All research analyses were done using statistical software SPSS $17.0^{\circ}$. 


\section{RESULTS}

This section presents the main results of the study, mainly focusing on the CA results (Hair, Jr. et. al 2005). The majority of respondents in the sample were males aged between 18 and 29 years old, single, and living in Minas Gerais state, with higher education, and a family income between $\mathrm{R} \$ 2,041.00$ and $\mathrm{R} \$ 5,100.00$. The researcher's social networks influenced these results since it is a convenience sample.

Attributes levels part-worth and attribute importance were estimated at the individual level before post hoc aggregated results (Hair, Jr. et. al 2005). This allowed us to predict the FMPs' best offer possibilities, based on both their characteristics and the individual choice model estimates. This is an effective approach for allowing marketers to identify the process which fans compare and evaluate FMPs' alternatives (Anand, Bansal, \& Aggrawal, 2018). However, it's important to emphasize the requirements to adapting marketing strategies for sports marketing, as pointed out by Baker, McDonald and Funk (2016), since it's a market with an unusual lack of "competing brands" (teams) from the point of view of the fans, since they are loyal to their teams.

Results indicate that, for the general sample, the perceived attribute with the highest value for the respondents is the "Price", and the level "R $\$ 20.00$ " was the one that presented the largest relative importance weight. Hinterhuber (2004) argues that the consumers' value perception in relation to a service, interferes with the price they are willing to pay.

The need for high-quality services has emerged as a value perception antecedent. Therefore, it is necessary to understand the interpreting ways and what constitutes a value offer in the user's perception, as consumers have become more selective with the offers, analyzing the total cost and not just the monetary one (Berry, Zeithaml, \& Parasuraman, 1985).

Next, the attribute "Discounts on tickets" received greater importance and the "90 \%" level was the most valued. Among their many benefits, FMPs have, as a main objective, to offer discounted tickets, which is a good option for clubs that usually do not fill all the stadiums' seats. This factor is usually associated with the sporting momentum experienced by the team (Itaú BBA, 2016) and such discounts encourage the fans' presence at matches.

Fanatical fans are present at most games, regardless of the importance of the match. However, Baker, McDonald and Funk (2016) recommend not to adopt strategies focused exclusively on this small number of fans, who consume in large quantities, but rather to invest in a broader base.

Next, it was verified that the construct "Benefits" received more importance, the preferred level being, "Discount in the network of partners." In Brazil, one of the FMPs' main supporters is the "Movement for Better Football." According to Martins (2016), these supporters aim to "leverage the club programs in Brazil by offering discounts on products and services of various brands to participants" (p. 11 independent translation). Therefore, it is noted that the "Partner Network Discount" and "Movement for a Better Football" levels, which were identified as higher and lower interest levels respectively, have similar purposes, so the results suggest that there is a preference for one and the other is not so relevant.

Thus, these findings demonstrate that fans' preferences vary, and it is necessary to identify which strategies are most effective for each plan. FMPs are models that use both the points accrual and consumer-level approach, which are the most popular loyalty program formats. Therefore, when a fan who is very proud of his team is identified, it may be an example of how emotions are prone to have the greatest impact on consumer-level models, as they provide the 
BBR

17

266

opportunity to signal a status, which is consistent with the pride role (Septianto, An, Chiew, Paramita, \& Tanudharma 2019).

The "Advance Purchase" benefit was identified as the fourth most important, being an attribute without differentiation levels, meaning that the respondent only opined "yes" or "no". The attribute refers to the possibility of associates acquiring tickets before other fans can buy them, which is attractive for the major championship finals, as in these cases, ticket demands are generally higher. In addition, it has also been considered advantageous for the clubs, since the fan, when becoming a member, undertakes to pay a monthly fee having, often, the possibility of buying tickets in advance. The discount offered to members is an amount referring to the ticket sales anticipation and games with a small turn out of fans form a part of the tickets revenue, which will already be guaranteed with the payment of the members' monthly fees.(Itaú BBA, 2016).

These results illustrate the need for sports managers to refine their relationship marketing strategies, seeking mutual benefits for all team stakeholders. Therefore, clubs should also pay attention to satisfaction and trust, and offer superior benefits in their value propositions (Demo et al., 2015; Lo \& Campos, 2018; Morgan and Hunt, 1994).

Figueiredo, Santos and Cunha (2016) reinforce that football is Brazil's most popular sport and it has a significant economic movement. In addition, Cardoso and Silveira (2014) point out that "fanatics are those who go most frequently to stadiums, but this group of fans is only a portion of the total number of fans" (p. 22 independent translation). Thus, the need to invest and diversify the FMPs' plans stays evident.

Subsequently, the attribute with greater importance was the possibility of including more dependents, being the option that allows customers to add "three dependents" the best-evaluated level. The smaller importance of this attribute may be a result of the sample structure by $62.2 \%$ of singles, respondents that probably have less dependents in average than married, divorced, or widowed football fans. As such, we need to take care when interpreting the general sample results for this attribute, since Family engagement in Brazil's Football context is strong, for example, in the influence parents have in their children's choice for the favorite soccer team (Macagnan $\&$ Betti, 2014). Finally, the attribute "Access to the Privileged Area" was what aroused the least interest in comparison to the others.

Therefore, considering that familiar context has a major influence on individual engagement with football, we may point out a great potential for implementing word-of-mouth communication strategies. "Rumor agents" are people who perceive other consumers as a reference source for a good. An unsatisfied fan with past cumulative performances and with high future dissatisfaction probability will present a high willingness to promote the organization negatively (Claro and Bortoluzzo, 2015; Weitzl, Hutzinger, \& Einwiller, 2018).

The results showed that a lower priced plan and higher ticket discounts have greater intentions to be bought, even if it does not grant access to the privileged area. However, when analyzing the results in a stratified form, it is noted that there are different preferences. Therefore, in a context of high variance in customer preferences, their needs have to be better mapped, being fundamental to know them to adjust the FMPs' profile to aim new value propositions targeting different segments (Hills, Walker e Barry, 2019; Sheth, Newman, \& Gross, 1991; Shin, Kim, $\&$ Severt, 2019). 
Chart 2 presents each attribute importance (percentage) for different sociodemographic profiles. To test such differences, the Analysis of Variance - ANOVA - was applied in order to identify groups' means variations. Thus, we tested the null hypothesis of equality by means of the dependent variables throughout the groups (Hair, Jr. et. al 2005). Therefore, all ( $<<0.05)$ were considered significant.

There is little difference in the importance estimates between men and women for FMPs' attributes. The attributes "Price", "Discount on Tickets" and "Advance Purchase" were of greater importance for men, while the attributes "Dependent", "Privileged Area" and "Benefits" were more important in the women's opinion. However, the differences did not exceed $2 \%$.

For age, "Price" and "Discount on tickets" continued to be the attributes most valued by respondents, except for those aged up to 17 years but this age group is not very representative in the present sample, corresponding to only $1 \%$ in the database. Nevertheless, the "Dependent" and "Privileged Area" constructs remained the least attractive in intent to purchase a Fan Membership Programs plan.

Sequentially, the division by marital status also had "Price" as the attribute most valued by the respondents, except by widowers. Thus, as it happened for the age group up to 17 years, such respondents are not very representative in the present sample, corresponding to only $0,5 \%$ of the total data base. Nevertheless, the "Privileged Area" construct remained the least attractive in intent to purchase a Fan Membership Programs plan.

As for schooling, "Price" and "Discount on the tickets" were also the attributes most valued by the respondents, except by those who only have High School who prefer the "Benefits" construct. The "Privileged Area" construct continued as the least attractive. Incomplete High School respondents were more distanced from the average general results, which represents $1.4 \%$ in the sample.

Following the same line, in the Family Income results, the "Price" and the "Discount on the tickets" continued to be attributes most valued by the respondents and the "Privileged Area" construct remained the least attractive in intention to purchase a Fan Membership Program. It was also observed that the respondents with incomes up to $\mathrm{R} \$ 1.020,00$ were the ones that more distanced themselves from the average general results.

The results show that academic tools can support sports managers. Especially considering that there are many sports organizations, especially small ones, which assign the marketing responsibility to an inexperienced employee, which can be detrimental to team goals (Dickler, 2015). 
BBR

17

268

Chart 2

Analysis of importance by sociodemographic characteristics

\begin{tabular}{|c|c|c|c|c|c|c|c|}
\hline \multirow{2}{*}{\multicolumn{2}{|c|}{ Sociodemographic Characteristics }} & \multicolumn{6}{|c|}{ Attribute in Importance Order } \\
\hline & & \multirow{2}{*}{$\begin{array}{l}\text { Price } \\
22 \%\end{array}$} & \multirow{2}{*}{$\begin{array}{c}\text { Discount } \\
\text { on tickets }\end{array}$} & \multirow{2}{*}{$\begin{array}{c}\text { Benefits } \\
19 \%\end{array}$} & \multirow{2}{*}{$\begin{array}{c}\text { Advanced } \\
\text { purchase }\end{array}$} & \multirow{2}{*}{$\begin{array}{c}\text { Dependents } \\
15 \%\end{array}$} & \multirow{2}{*}{$\begin{array}{c}\begin{array}{c}\text { Privileged } \\
\text { area }\end{array} \\
9 \%\end{array}$} \\
\hline Cenre & Female & & & & & & \\
\hline Gentre & Male & $23 \%$ & $22 \%$ & $18 \%$ & $17 \%$ & $13 \%$ & $7 \%$ \\
\hline \multirow{5}{*}{ Age range } & Up to 17 years & $15 \%$ & $19 \%$ & $20 \%$ & $18 \%$ & $15 \%$ & $13 \%$ \\
\hline & $18-29$ years old & $21 \%$ & $24 \%$ & $18 \%$ & $15 \%$ & $13 \%$ & $8 \%$ \\
\hline & $30-39$ years & $23 \%$ & $20 \%$ & $18 \%$ & $17 \%$ & $14 \%$ & $7 \%$ \\
\hline & $40-49$ years & $29 \%$ & $18 \%$ & $17 \%$ & $15 \%$ & $15 \%$ & $6 \%$ \\
\hline & 50 years or more & $24 \%$ & $18 \%$ & $20 \%$ & $17 \%$ & $15 \%$ & $6 \%$ \\
\hline \multirow{4}{*}{$\begin{array}{l}\text { Marital } \\
\text { status }\end{array}$} & Single (a) & $22 \%$ & $23 \%$ & $18 \%$ & $16 \%$ & $13 \%$ & $8 \%$ \\
\hline & Married (a) & $23 \%$ & $20 \%$ & $17 \%$ & $16 \%$ & $15 \%$ & $8 \%$ \\
\hline & Widower (a) & $11 \%$ & $41 \%$ & $20 \%$ & $8 \%$ & $11 \%$ & $8 \%$ \\
\hline & Divorced (a) & $24 \%$ & $19 \%$ & $23 \%$ & $14 \%$ & $15 \%$ & $5 \%$ \\
\hline \multirow{5}{*}{ Schooling } & Incomplete fundamental & $15 \%$ & $26 \%$ & $24 \%$ & $14 \%$ & $18 \%$ & $4 \%$ \\
\hline & Incomplete High school & $15 \%$ & $19 \%$ & $16 \%$ & $18 \%$ & $17 \%$ & $14 \%$ \\
\hline & High school & $21 \%$ & $19 \%$ & $21 \%$ & $13 \%$ & $15 \%$ & $10 \%$ \\
\hline & Incomplete Higher & $22 \%$ & $24 \%$ & $18 \%$ & $14 \%$ & $14 \%$ & $8 \%$ \\
\hline & Higher education & $23 \%$ & $21 \%$ & $18 \%$ & $17 \%$ & $14 \%$ & $7 \%$ \\
\hline \multirow{6}{*}{$\begin{array}{l}\text { Family } \\
\text { income } \\
\text { (Values } \\
\text { in real } \\
\text { Brazilian) }\end{array}$} & Up to $1,020.00$ & $17 \%$ & $24 \%$ & $23 \%$ & $10 \%$ & $18 \%$ & $9 \%$ \\
\hline & From $1,021.00$ to $2,040.00$ & $21 \%$ & $23 \%$ & $21 \%$ & $13 \%$ & $14 \%$ & $9 \%$ \\
\hline & From $2,041.00$ to $5,100.00$ & $24 \%$ & $22 \%$ & $18 \%$ & $15 \%$ & $13 \%$ & $8 \%$ \\
\hline & From $5,101.00$ to $10,020.00$ & $23 \%$ & $21 \%$ & $18 \%$ & $17 \%$ & $14 \%$ & $7 \%$ \\
\hline & Above $10,021.00$ & $21 \%$ & $21 \%$ & $17 \%$ & $19 \%$ & $14 \%$ & $8 \%$ \\
\hline & Overall Result & $22 \%$ & $22 \%$ & $18 \%$ & $16 \%$ & $14 \%$ & $8 \%$ \\
\hline
\end{tabular}

Source: search data

\section{CONCLUSION}

This study shows that, in the general sample, the attribute "Price" has a significant impact on the purchase decision and in the FMPs' plans for value perception. The "Discount on the tickets" was the second most significant. The literature considers the attribute as one of the FMP main objectives (Itaú BBA, 2016). In terms of levels, the "Discount in partner network" was the level most valued of attribute "Benefits", followed by "Early purchase", the inclusion of three dependents, and, lastly, access to the privileged area. While consumers that have become more selective by looking at the total cost, not just the monetary, it is clear that the financial dimension still has significant influence and the value of perception interferes with the price fans are willing to pay.

The sociodemographic characteristics results indicate that there is little difference in preference between men and women. However, those attributes that related to the financial values (price, discount on the tickets, and advance purchase) are of greater importance to men. While the 
attributes related to convenience (dependents, privileged area, and benefits) were more important in the opinion of women.

Thus, this evidence reinforces that fans' preferences vary, and it is necessary to identify which strategies are most effective for each plan. In addition to offering plans with accumulation points and consumer level options, it is worth considering the alternative for fans to select their own interest attributes.

For the age range significant differences were found. For respondents up to the age of 17, "Benefit" was the most valued attribute, but the 20-29 age group attributed greater value to "Discount on the tickets". All respondents aged 30 years or more evaluated the "Price" as the highest value attribute. The attribute "Discount on tickets" resulted in greater opinions divergence between the ages range.

In comparing marital status, singles value the "discount on the tickets" more, while the divorced and married prioritize the "Price". The widowers rated "Benefit" as the most important attribute. The attribute "Discount on the tickets" was the one that presented greater opinions divergence comparing with the other attributes.

As for schooling, it was found that the participants who had completed Higher Secondary School gave a better evaluation for the "Benefits" construct. Those with complete Higher Education preferred the "Price", and those with incomplete High School and incomplete Higher Education gave more importance to the "Discount on the tickets". Participants with incomplete secondary education and incomplete elementary education were not included since, together, they represented only $1.6 \%$ of the total database.

In Family Income results, it was verified that those with an income of up to $\mathrm{R} \$ 1,020.00$ valued "Discount on the tickets" as the most important attribute and according to the increased income the "Price" became the most valuable attribute, except for the respondents with an income above $\mathrm{R} \$ 10,021.00$ who attributed the same importance to both attributes. Therefore, those who had an income up to $\mathrm{R}$ \$2,040.00 gave more importance to the discount on tickets, and those that were in the range of $\mathrm{R} \$ 2,041.00$ to $\mathrm{R} \$ 10,020.00$ gave more importance to the price. The attribute "Advance Purchase" resulted in a greater opinions divergence.

The sample representativeness is the main study limitation. We opted for convenience sampling and no measures were taken to stratify it. Thus, the sociodemographic characteristics representativeness became unbalanced, which made it difficult to prove certain premises, such as the preference for a plan with dependents. A biased representation by region also occurred, since the majority of the respondents reside in the Southeast and cheer for teams in that region. Therefore, we suggest the adoption of stratified sampling for future research, in order to elucidate differences by segments more clearly.

The "Dependents" construct, which was evaluated in the general sample as the penultimate preference, suggests that this fact may have occurred due to a large number of singles present in the sample $(62.2 \%)$. The plans that include family members arouses more of an interest in the people who have children, which is more common among married, divorced, and widowed people. Such a premise becomes more convincing by observing the results stratified by marital status, since the highest mean of importance in the construct was that of married respondents, followed by divorcees and having singles as their last preference.

Therefore, we recommend that future research adopt a stratified sample to prove this premise, especially considering the influence that family involvement has on the context of Football and the consequences of these relationships. For example, a fan may possibly communicate his or 
BBR

17

270

her experience to those close to him or her by implementing word of mouth communication strategies that may alert or recommend the organization involved.

As for the instrument utilized, Kendall's agreement coefficient was applied to determine the agreement between the real preferences and the ones predicted by the CA (Benitez \& Golinski, 2007). We used the significance level for the cut-off point, because if we have chosen Kendall's agreement coefficient, (W) that ranges from 0 to 1 , we would have to consider values above (W $\geq 0.66$ ), as affirms Conover (1971 cited by Lima et al. 2012, p.6), as indicative that the model was able to foresee the respondents' preference. If we had used such a measure, the sample would have been significantly reduced. Therefore, we suggest for future research to adopt stratified sampling in order to soften such limitations.

The present work, contributed to football clubs' FMPs', applies the value structure-mapping proposal. In addition, the article may be useful to encourage sports managers to seek both compressions: the best benefits to offer and the identification of FMPs' good points. In addition, it is evident that sports managers need to improve their relationship marketing strategies by investing and diversifying FMP plans, strengthening satisfaction and trusting relationships, and offering superior offers and benefits.

Although, in general, ticket price and discount were the most valued attributes and the privileged area of least interest, some peculiarities in preferences imply that value is a multidimensional construct with several possibilities to compose new proposals value and FMP plans preparation.

\section{REFERENCES}

Anand, A., Bansal, G., \& Aggrawal, D. (2018). Choice based diffusion model for predicting sales of mobile phones using conjoint analysis. The Journal of High Technology Management Research, 29(2), 216-226. https://doi.org/10.1016/j.hitech.2018.09.008

Avancini, J., Souza, A., Butier, L. R., \& Saling, R. (2010). Sport Club Internacional 100 anos, 100 mil sócios. ESPM Central de Cases, 2-14.

Baker, B. J., McDonald, H., \& Funk, D. C. (2016). The uniqueness of sport: Testing against marketing's empirical laws. Sport Management Review, 19(4), 378-390. https://doi.org/10.1016/j. smr.2016.02.002

Benitez, R. M., \& Golinski, I. (2007). A agricultura orgânica como estratégia alternativa em busca da sustentabilidade - Uma análise estatística da organização atual. Revista de Administração e Inovação, 4(2), 117-132. https://doi.org/10.5380/dma.v41i0.49766

Berry, L.L. (1983). Relationship marketing. In Berry, L.L., Shostack, G.L. and Upah, G.D. (Eds). Emerging Perspectives of Services Marketing (pp. 25-28). Chicago, IL: American Marketing Association.

Berry, L. L., Zeithaml, V. A., \& Parasuraman, A. (1985). Quality counts in services, too. Business Horizons, 28(3), 44-52. https://doi.org/10.1016/0007-6813(85)90008-4

Biscaia, R., Ross, S., Yoshida, M., Correia, A., Rosado, A., \& Marôco, J. (2016). Investigating the role of fan club membership on perceptions of team brand equity in football. Sport Management Review, 19(2), 157-170. https://doi.org/10.1016/j.smr.2015.02.001

Caliskan, A., \& Esmer, S. (2019). Does it really worth investing in relationship marketing for a port business? Case Studies on Transport Policy, 7(2), 375-383. https://doi.org/10.1016/j.cstp.2019.02.003 
Cardoso, M. V., \& Silveira, M. P. (2014). A importância da adoção do sócio torcedor como estratégia de inovação para aumentar as receitas dos clubes de futebol no Brasil. Podium Sport. Leisure and Tourism Review, 3(3), 12-24. https://doi.org/10.5585/podium.v3i3.99

Casper, J. M., McCullough, B. P., \& Pfahl, M. E. (2019). Examining environmental fan engagement initiatives through values and norms with intercollegiate sport fans. Sport Management Review. Advance online publication. https://doi.org/10.1016/j.smr.2019.03.005

Chang, C., \& Dibb, S. (2012). Reviewing and conceptualising customer-perceived value. The Marketing Review, 12(3), 253-274. https://doi.org/10.1362/146934712X13420906885395

Chaves, P. G., Gosling, M., \& Medeiros, S. A. (2014). Engajamento e ações de marketing de relacionamento no futebol: Um estudo com torcedores do Cruzeiro Esporte Clube. Revista das Faculdades Integradas Viana Júnior, 5(1), 201-232.

Claro, D. P., \& Bortoluzzo, A. B. (2015). Profiling the Buzz Agent: Product Referral and the Study of Social Community and Brand Attachment. Brazilian Administration. Review, 12(2), 209-228. https://doi.org/10.1590/1807-7692bar2015140076

da Costa, M. F., Costa, C. E., de Angelo, C. F., \& de Moraes, W. F. A. (2018). Perceived competitive advantage of soccer clubs: A study based on the resource-based view. RAUSP Management Journal, 53(1), 23-34. https://doi.org/10.1016/j.rauspm.2016.08.001

de Boer, E. R., \& Gudmundsson, S. V. (2012). 30 years of frequent flyer programs. Journal of Air Transport Management, 24, 18-24. https://doi.org/10.1016/j.jairtraman.2012.05.003

Demo, G., Fogaça, N., Ponte, V., Fernandes, T., \& Cardoso, H. (2015). Marketing de relacionamento (CRM): estado da arte, revisão bibliométrica da produção nacional de primeira linha, institucionalização da pesquisa no brasil e agenda de pesquisa. Revista de Administração Mackenzie, 16(5), 127-160.

Dickler, L. (2015). [Review of the book: Strategic Sport Marketing, D. Shilbury, H. Westerbeek, S. Quick, D. Funk, A. Karg]. Sport Management Review, 18(4), 627-628. https://doi.org/10.1016/j. smr.2014.09.004

Ferreira, J. C., \& Patino, C. M. (2015). O que realmente significa o valor-p? Jornal Brasileiro de Pneumologia, 41(5), 485. https://doi.org/10.1590/S1806-37132015000000215

Figueiredo, G. H., Santos, V., \& Cunha, P. R. (2017). Práticas de Evidenciação em Entidades Desportivas: Um Estudo nos Clubes de Futebol brasileiro. Enfoque: Reflexão Contábil, 36(1), 1-21. https://doi.org/10.4025/enfoque.v36i1.28467

Fleury, F. A., Nogami, V.K. C., Mazzon, J.A., Veloso, A. R. (2016). Efeito das Vitórias e Derrotas na Atitude do Torcedor de Futebol: Um Estudo Envolvendo Garoto-Propaganda, Envolvimento e Fanatismo. Brazilian Business Review, 13(4), 25-50. https://doi.org/10.15728/bbr.2016.13.4.2

Gaspar, M. A., Morais, D. M. G., Vallada Júnior, A. C., \& Debia, C. A. (2014). Marketing Esportivo: Um Estudo das Açóes Praticadas por Grandes Clubes de Futebol do Brasil. Podium Sport. Leisure and Tourism Review, 3(1), 12-28. https://doi.org/10.5585/podium.v3i1.67

Grönroos, C. (1994). From Marketing Mix to Relationship Marketing. Management Decision, 32(2), 4-20. https://doi.org/10.1108/00251749410054774

Hair, J. F., Jr., Anderson, R. E., Tatham, R. L. \& Black, W. C. (2005). Análise multivariada de dados (5th ed.). Porto Alegre, BR: Bookman

Hennig-Thurau, T., Gwinner, K. P., \& Gremler, D. D. (2002). Understanding Relationship Marketing Outcomes. Journal of Service Research, 4(3), 230-247. https://doi.org/10.1177/1094670502004003006 
BBR

17

272

Hills, S., Walker, M., \& Barry, A. E. (2019). Sport as a vehicle for health promotion: A shared value example of corporate social responsibility. Sport Management Review, 22(1), 126-141. https://doi. org/10.1016/j.smr.2018.10.001

Hinterhuber, A. (2004). Towards value-based pricing - An integrative framework for decision making. Industrial Marketing Management, 33(8), 765-778. https://doi.org/10.1016/j. indmarman.2003.10.006

Huertas-García, R., Nuñez-Carballosa, A., \& Miravitlles, P. (2016). Statistical and cognitive optimization of experimental designs in conjoint analysis. European Journal of Management and Business Economics, 25(3), 142-149. https://doi.org/10.1016/j.redee.2015.10.001

Itaú BBA. (2016). Análise Econômico-Financeira dos Clubes Brasileiros de Futebol. https://pt.slideshare. net/cassiozipa/anlise-dos-clubes-brasileiros-2016-ita-bba

Johnson, E. J., \& Meyer, R. J. (1984). Compensatory Choice Models of Noncompensatory Processes: The Effect of Varying Context. The Journal of Consumer Research, 11(1), 528. https:// doi.org/10.1086/208989

Kasiri, L. A., Guan Cheng, K. T., Sambasivan, M., \& Sidin, S. M. (2017). Integration of standardization and customization: Impact on service quality, customer satisfaction, and loyalty. Journal of Retailing and Consumer Services, 35, 91-97. https://doi.org/10.1016/j.jretconser.2016.11.007

Lo, F. Y., \& Campos, N. (2018). Blending Internet-of-Things (IoT) solutions into relationship marketing strategies. Technological Forecasting and Social Change, 137, 10-18. https://doi. org/10.1016/j.techfore.2018.09.029

Lois, N. C. (2013). Estratégias empiricas em patrocínio esportivo à luz da experiência de organizaçóes esportivas e empresas investidoras. (Tese de doutorado). https://repositorio.ufsc.br/xmlui/ handle/123456789/123099

Macagnan, L. D. G., \& Betti, M. (2014). Futebol: Representaçôes e práticas de escolares do ensino fundamental. Revista Brasileira de Educação Física e Esporte, 28(2), 315-327. https://doi. org/10.1590/1807-55092014000200315

Marques, D. S. P., \& Costa, A. L. (2016). Administração de clubes de futebol profissional: Proposta de um modelo específico de governança para o setor. Organizaçóes \& Sociedade, 23(78), 378-405. https://doi.org/10.1590/1984-92307823

Martins, F. F. (2016). Marketing de relacionamento no futebol: O programa sócio-torcedor do Sport Club Corinthians Paulista. (Dissertação de Mestrado). https://tede2.pucsp.br/handle/handle/19050

Moraes, I. F. (2017). Marketing esportivo no futebol: Produção e publicação acadêmica brasileira. Revista Intercontinental de Gestão Desportiva, 7(2), 193-213.

Morgan, R. M., \& Hunt, S. D. (1994). The Commitment-Trust Theory of Relationship Marketing. Journal of Marketing, 58(3), 20-38. https://doi.org/10.1177/002224299405800302

Müller, O., Simons, A., \& Weinmann, M. (2017). Beyond crowd judgments: Data-driven estimation of market value in association football. European Journal of Operational Research, 263(2), 611-6241. https://doi.org/10.1016/j.ejor.2017.05.005

Myskiw, M. (2006). Marketing Esportivo no Futebol: um olhar à luz do paradigma do marketing de relacionamento (Dissertação de Mestrado). https://repositorio.ufsm.br/handle/1/4517

Nuraeni, S., Arru, A. P., \& Novani, S. (2015). Understanding Consumer Decision-making in Tourism Sector: Conjoint Analysis. Procedia: Social and Behavioral Sciences, 169, 312-317. https://doi. org/10.1016/j.sbspro.2015.01.315 
Oliver, R. L. (1997). Satisfaction: a behavioral perspective on the consumer. New York, NY: The McGraw-Hill.

Park, E., Kim, K. J., \& Kwon, S. J. (2017). Corporate social responsibility as a determinant of consumer loyalty: An examination of ethical standard, satisfaction, and trust. Journal of Business Research, 76, 8-13. https://doi.org/10.1016/j.jbusres.2017.02.017

Pitts, B. G., \& Stotlar, D. K. (2002). Fundamentos de marketing esportivo. São Paulo, BR: Phorte.

Pozzi, L. F. (1998). A grande jogada. São Paulo, BR: Globo.

Rossi, C. A. V., \& Slongo, L. A. (1998). Pesquisa de satisfação de clientes: O estado-da-arte e proposição de um método brasileiro. Revista de Administração Contemporânea, 2(1), 101-125. https://doi.org/10.1590/S1415-65551998000100007

Scharf, E. R., Sousa, R. P. L., Sarquis, A. B., Belz, E. (2017). A experiência e mais dez: Uma estratégia para vencer na Champions League. Gestão \& Regionalidade, 32(96), 21-34. https://doi. org/10.13037/gr.vol32n96.3461

Septianto, F., An, J., Chiew, T. M., Paramita, W., \& Tanudharma, I. (2019). The similar versus divergent effects of pride and happiness on the effectiveness of loyalty programs. Journal of Business Research, 99, 12-22. https://doi.org/10.1016/j.jbusres.2019.02.021

Sheth, J. N., Newman, B. I., \& Gross, B. L. (1991). Why we buy what we buy: A theory of consumption values. Journal of Business Research, 22(2), 159-170. https://doi.org/10.1016/01482963(91)90050-8

Sheth, J. N., \& Parvatiyar, A. (1995). The evolution of relationship marketing. International Business Review, 4(4), 397-418. https://doi.org/10.1016/0969-5931(95)00018-6

Shin, Y. H., Kim, H., \& Severt, K. (2019). Consumer values and service quality perceptions of food truck experiences. International Journal of Hospitality Management, 79, 11-20. https://doi. org/10.1016/j.ijhm.2018.12.008

Souza, E. M., \& Batista, P. C. S. (2017). Antecedentes e Consequentes Estratégicos para o Desempenho de Empresas de E-Business. Brazilian Business Review, 14(1), 59-86. https://doi.org/10.15728/ bbr.2017.14.1.4

Steinhoff, L., \& Palmatier, R. W. (2016). Understanding loyalty program effectiveness: Managing target and bystander effects. Journal of the Academy of Marketing Science, 44(1), 88-107. https:// doi.org/10.1007/s11747-014-0405-6

Vrontis, D., Thrassou, A., Kartakoullis, N. L., \& Kriemadis, T. (2014). Strategic marketing planning for football clubs: A value-based analysis. Journal for Global Business Advancement, 7(4), 355-374. https://doi.org/10.1504/JGBA.2014.065593

Weitzl, W., Hutzinger, C., \& Einwiller, S. (2018). An empirical study on how webcare mitigates complainants' failure attributions and negative word-of-mouth. Computers in Human Behavior, 89, 316-327. https://doi.org/10.1016/j.chb.2018.07.012

Yang, H., Yu, J., Zo, H., \& Choi, M. (2016). User acceptance of wearable devices: An extended perspective of perceived value. Telematics and Informatics, 33(2), 256-269. https://doi.org/10.1016/j. tele.2015.08.007

Yegoryan, N., Guhl, D., \& Klapper, D. (2019). Inferring attribute non-attendance using eye tracking in choice-based conjoint analysis. Journal of Business Research. Advance online publication. https:// doi.org/10.1016/j.jbusres.2019.01.061 
BBR

17

274
Zeithaml, V. A., Bitner, M. J., \& Gremler, D. D. (2014). Marketing de Serviços: A empresa com foco no cliente (6th ed.). São Paulo, BR: AMGH Editora.

\section{AUTHOR'S CONTRIBUTION}

Introduction, references and conclusions - First author.

Method, results, discussions - Second author

\section{FINANCIAL SUPPORT}

This study was financed in part by the Coordenação de Aperfeiçoamento de Pessoal de Nível Superior - Brasil (CAPES) - Finance Code 001

\section{CONFLICTS OF INTEREST}

The authors declare no conflicts of interest. 